(c) 2020, The Authors. Published by FASS Inc. and Elsevier Inc. on behalf of the American Dairy Science Association ${ }^{\circledR}$. This is an open access article under the CC BY-NC-ND license (http://creativecommons.org/licenses/by-nc-nd/4.0/).

\title{
Analysis of closed versus operating dairies in the southeastern United States
}

\author{
Jade Ellis, ${ }^{1}$ Karen L. DeLong, ${ }^{1 *}$ ๑ Dayton M. Lambert, ${ }^{2}$ Susan Schexnayder, ${ }^{3} \odot$ Peter Krawczel, ${ }^{4} \odot$ \\ and Steve Oliver ${ }^{4}$ \\ ${ }^{1}$ Department of Agricultural and Resource Economics, University of Tennessee, Knoxville 37996 \\ ${ }^{2}$ Department of Agricultural Economics, Oklahoma State University, Stillwater 74078 \\ ${ }^{3}$ Department of Forestry, Wildlife and Fisheries, University of Tennessee, Knoxville 37996 \\ ${ }^{4}$ Department of Animal Science, University of Tennessee, Knoxville 37996
}

\begin{abstract}
This study analyzed differences between dairies that have closed compared with dairies still operating in the southeastern United States. Significant changes have occurred in the US dairy industry in the last decade, involving the number of dairy farms, herd size, milk quality, and management practices, yet the dairy industry remains the fourth leading agricultural sector in the United States, with $\$ 38$ billion of milk sales in 2017. Although the number of dairy cows in the United States has remained relatively constant over the past decade, at approximately 9 million head, the number of dairy operations has decreased by $30 \%$, resulting in larger dairies. This trend is even more prevalent in the southeastern United States, where the number of dairies has decreased by $39 \%$ from 5,315 in 2008 to only 3,235 in 2017. Additionally, downward pressure on bulk tank somatic cell count, which is used as a milk quality metric and has implications regarding animal health, intensified with US processors' introduction of incentive and penalty systems for quality milk production, necessitating better management of mastitis in dairy herds. In this context, this study examines factors that affect southeastern US dairy farms' persistence in the industry by using primary survey data collected in 2013 through a mail survey of Grade A dairies in Georgia, Mississippi, Kentucky, North Carolina, South Carolina, Tennessee, and Virginia. Dairies that were no longer operational had exited the industry from 2007 through 2014. A probit regression was used to determine which farm and operator characteristics were associated with the dairy's operational status. Dairy farms with more cows and higher average milk production per cow were more likely to be operational. For an additional $10 \mathrm{~kg} / \mathrm{d}$ of milk production per cow, the dairy was $1.5 \%$ more likely to be operational. For each 100 additional cows a
\end{abstract}

Received August 29, 2019.

Accepted February 1, 2020.

*Corresponding author: kdelong39@utk.edu dairy had, it was $4 \%$ more likely to be operational. The analysis also identifies nonpecuniary determinants of operational status for southeastern US dairies, such as mastitis management practices. Findings suggest that operations capable of leveraging scale effects are more likely to remain operational, with results affirming the consolidation of the US dairy industry and demonstrating that more productive farms are more likely to stay in operation. Results also suggest that factors other than farm size affect a dairy's operational status.

Key words: southeastern US dairies, closed versus operational dairies, probit regression, mastitis, survey

\section{INTRODUCTION}

The United States dairy industry generated $\$ 38$ billion from dairy product and milk sales in 2017, making it one of the top agricultural products in the United States, following cattle and calves, corn, and soybeans (USDA ERS, 2019; USDA NASS, 2018). In 2008, the United States was home to 57,127 dairy operations. By 2017, total operations had decreased by $30 \%$ to 40,219 (Figure 1a; USDA NASS, 2019). The average farm size for a US dairy in 2008 was 165 cows per farm, whereas the average farm size for 2018 was 234 cows per farm, an increase of $42 \%$ (LMIC, 2019a; USDA NASS, 2019). The number of dairy operations has decreased, but the total number of dairy cows in the United States has been fairly constant for the past 2 decades, at approximately 9 million head (Figure 1a; LMIC, 2019a). As of 2017, US milk production was 98 billion kilograms, up $13 \%$ from 2008 (Figure 1b), even though the total number of dairy cows remained constant (LMIC, 2019a). Over the same decade, average annual milk productivity per cow increased 12\%, from 9,250 kg to 10,404 kg (Figure 1b; LMIC, 2019a).

The US dairy industry has experienced several structural changes over the past decade, including a decrease in the number of dairy farms, increasing numbers of cows per operation, and increased cow productivity. Additionally, in the United States, Grade A dairy farms 
are permitted to ship milk only if they report a bulk tank SCC (BTSCC) of less than 750,000 cells $/ \mathrm{mL}$. There is pressure on the US dairy industry to reduce the maximum BTSCC to 400,000 cells/mL to maintain a spot in the competitive global export market (USDA APHIS, 2018). Mastitis is one of the most common diseases affecting dairy cattle and reduces milk production (National Mastitis Council, 1999; Pighetti and Elliott, 2011). The BTSCC is a metric used to detect mastitis infections and serves as a metric for milk quality (Oliver et al., 2004). Some states impose BTSCC restrictions, and many processors and milk co-operatives offer incentive and penalty pricing for quality milk reflecting consumer expectations for milk quality (Barkema et al., 2015; USDA APHIS, 2018).

This pressure exists along with producers facing lower US milk prices. The average nominal Class I fluid milk price in 2008 was $\$ 18.33$ per hundredweight

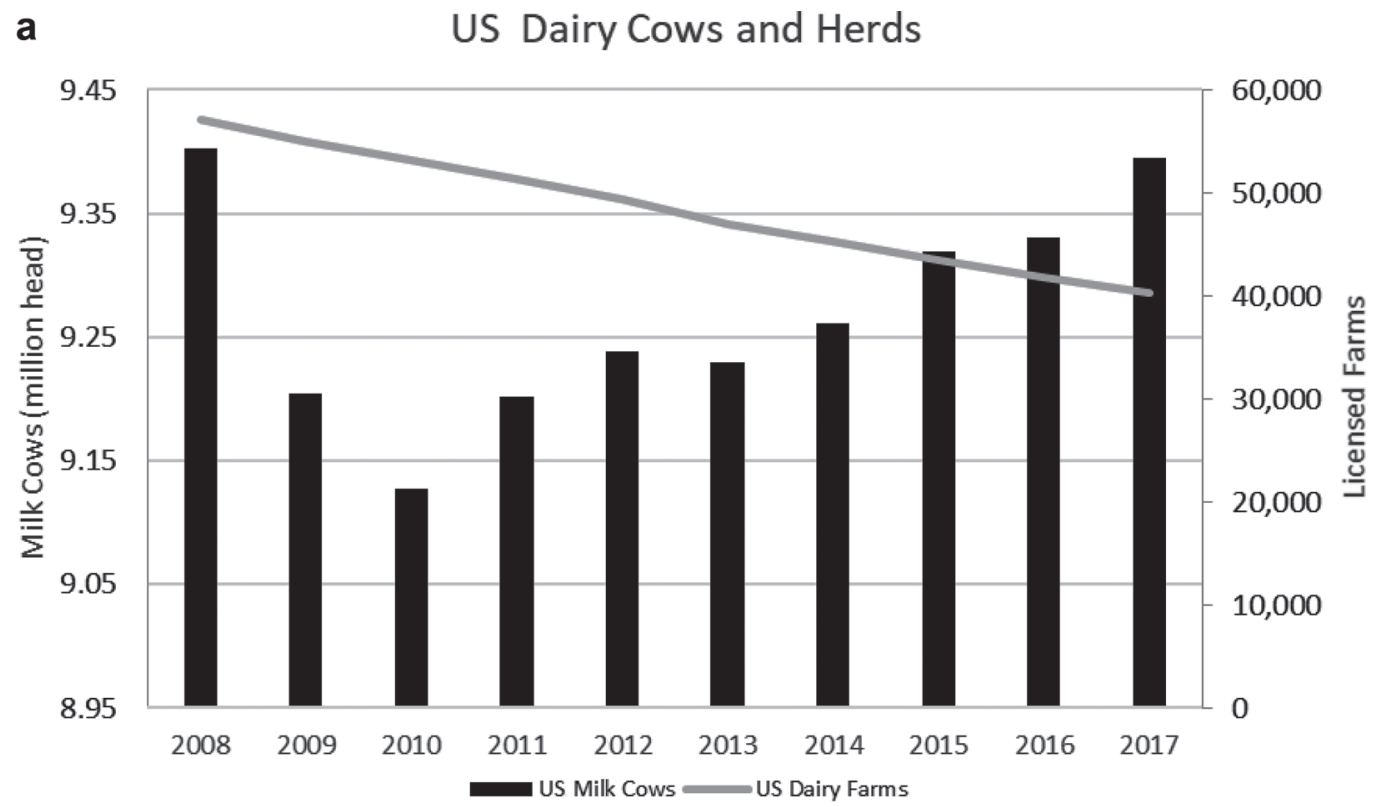

b

US Milk Production

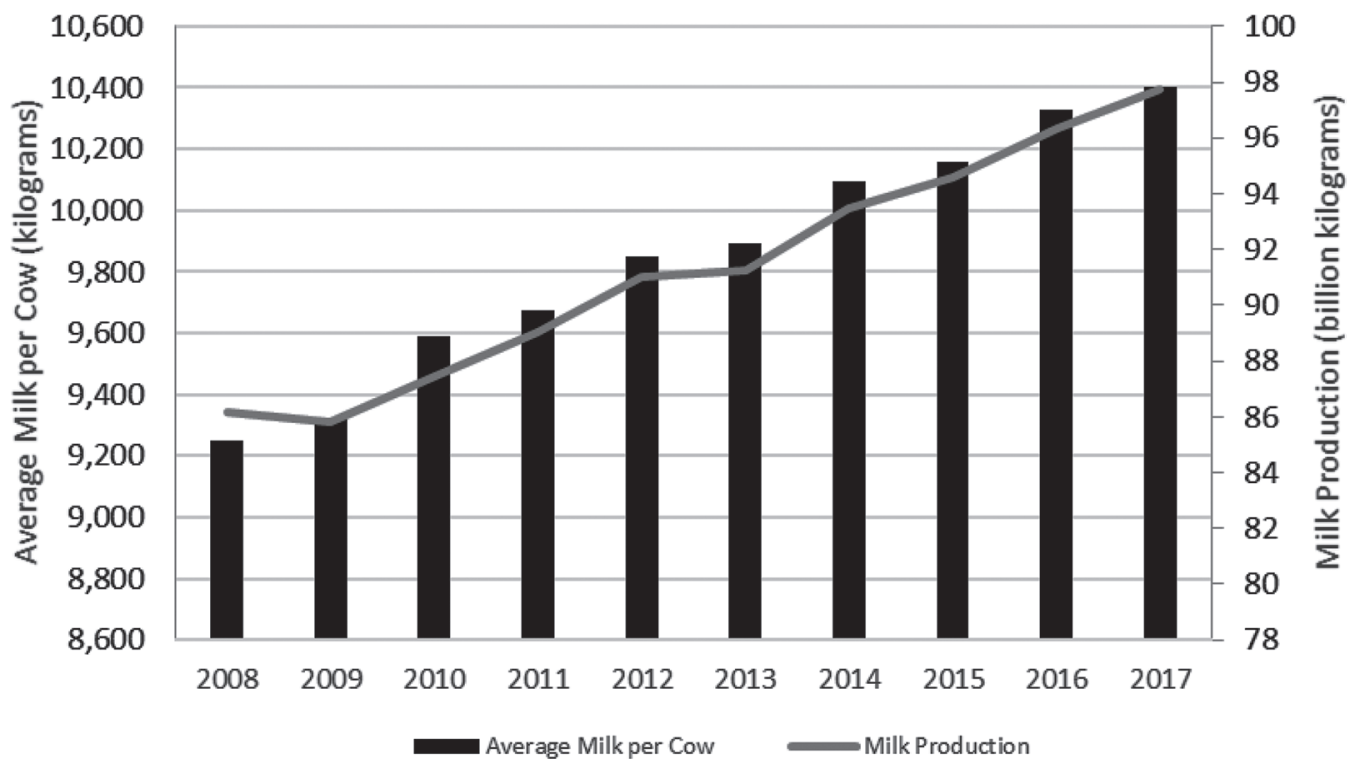

Figure 1. (a) Numbers of US dairy cows and herds, 2008 to 2017; (b) US annual dairy production, 2008 to 2017. Sources: LMIC (2019a), USDA NASS (2019). 


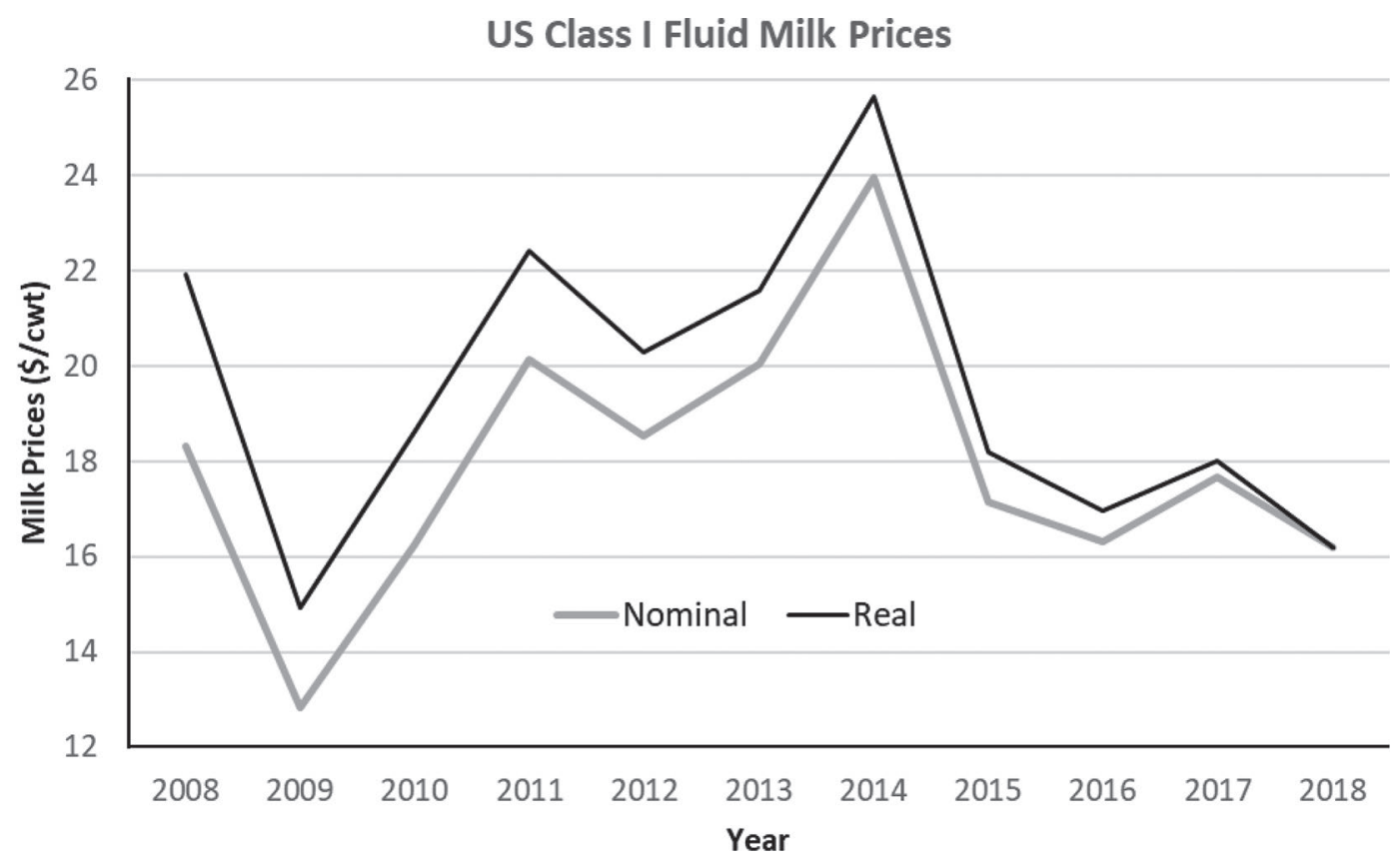

Figure 2. United States Class I fluid milk prices, 2008 to 2018. Source: LMIC, 2019b. Note: Inflation was accounted for by using the Consumer Price Index, adjusted to 2018 dollars (United States Department of Labor, 2019).

(cwt), whereas prices in 2018 were $\$ 16.18 /$ cwt, a $12 \%$ decrease over the past decade (LMIC, 2019b). However, it is important to note the volatility of milk prices during this period, which can be seen in Figure 2, adjusted (real) and not adjusted (nominal) for inflation. In just 4 years, prices declined $33 \%$ from the 2014 high of $\$ 24$ / cwt to $\$ 16.18 /$ cwt in 2018 . This price volatility has likely had a large effect on the operational status of dairies.

The structural changes and management challenges in the dairy sector are also evident in the southeastern United States, where milk productivity is lower than the national average. We define the southeastern United States to consist of the following states: Tennessee, Kentucky, North Carolina, South Carolina, Georgia, Mississippi, Missouri, Florida, Virginia, Alabama, and Louisiana. Milk production in the southeastern United States in 2017 was 4.82 billion $\mathrm{kg}$, which accounts for only $5 \%$ of the total milk produced by the United States (LMIC, 2019a). In the Southeast, average production per cow in 2017 was $8,564 \mathrm{~kg}$, whereas the average for the United States was 10,404 kg (Figure 3b; LMIC 2019a). In the past decade, southeastern US milk production has decreased by $3 \%$ (Figure $3 \mathrm{~b}$ ), and the number of dairy cows in the Southeast decreased by $17 \%$ from 676,000 to 563,000 (Figure 3a; LMIC, 2019a). The number of southeastern dairy farms has declined by $39 \%$, from 5,315 in 2008 to only 3,235 in 2017 (Figure 3a; USDA-NASS, 2019). During this same decade, average southeastern dairy herd sizes increased by $37 \%$, from 127 cows per farm to 174 cows per farm (LMIC, 2019a; USDA-NASS 2019). According to Herndon (2011), dairy farms in the southeastern United States are expected to decline by $57 \%$ from 2010 to 2025. The southeastern United States has also lagged behind the United States in lowering BTSCC levels. In 2012, $37 \%$ of US bulk tank milk samples had BTSCC less than 200,000 cells $/ \mathrm{mL}$, compared with only $21 \%$ in the Southeast (USDA-APHIS, 2013; Pighetti et al., 2014).

The number of dairy farms in the United States, and particularly in the southeastern United States, has been steadily declining. The goal of the present research is to analyze the factors influencing a dairy farm to be operational as opposed to closed. This study analyzes a survey of southeastern United States dairies to examine the differences between dairies that have exited the industry and dairies that have adapted to changing economic conditions, by considering the relationship between operational status and operator and operation characteristics related to mastitis management. In particular, our analysis focuses on the business characteristics, operator attributes, dairy management practices (e.g., mastitis management practices), and sources of information operators used to treat or control mastitis and their influence on the likelihood that a dairy farm remains in business in the southeastern United States. 
a

Southeastern US Dairy Cows and Herds

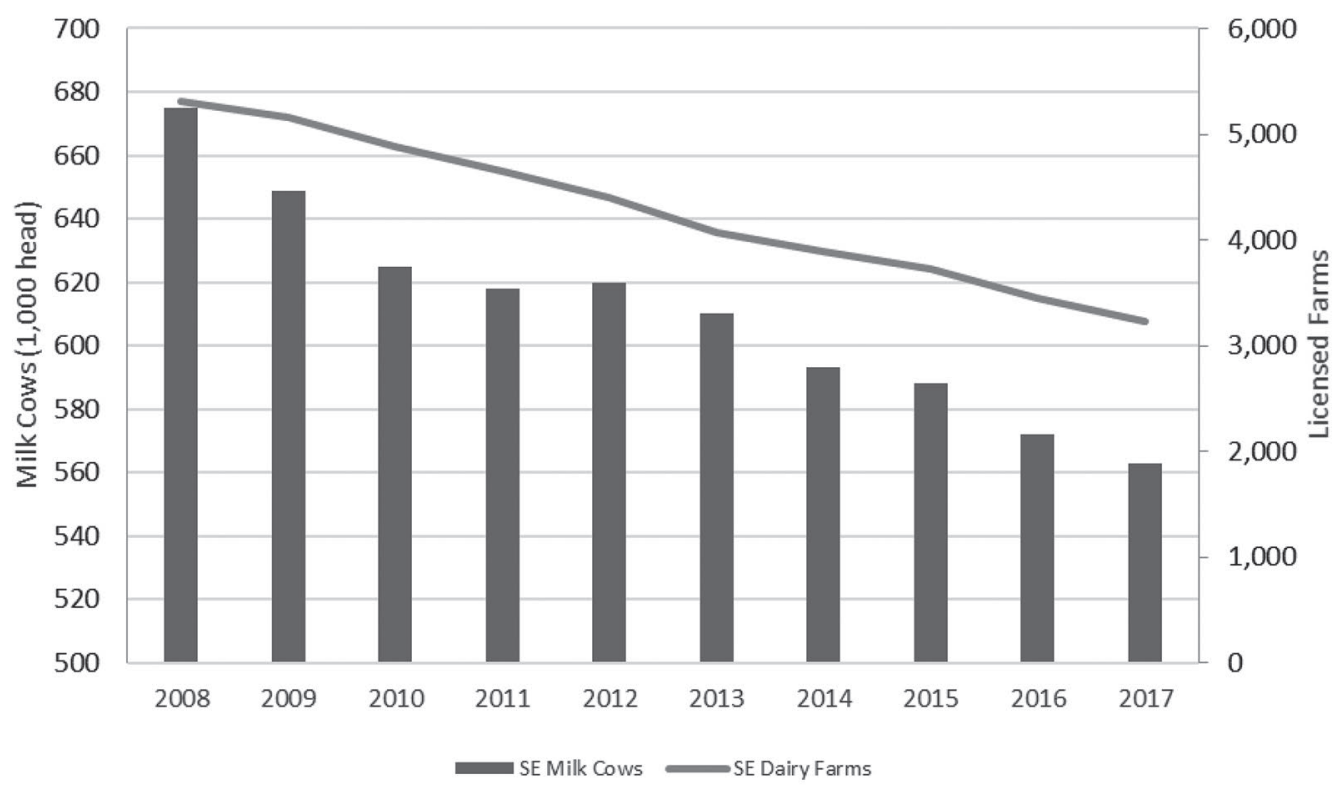

b

\section{Southeastern US Production}

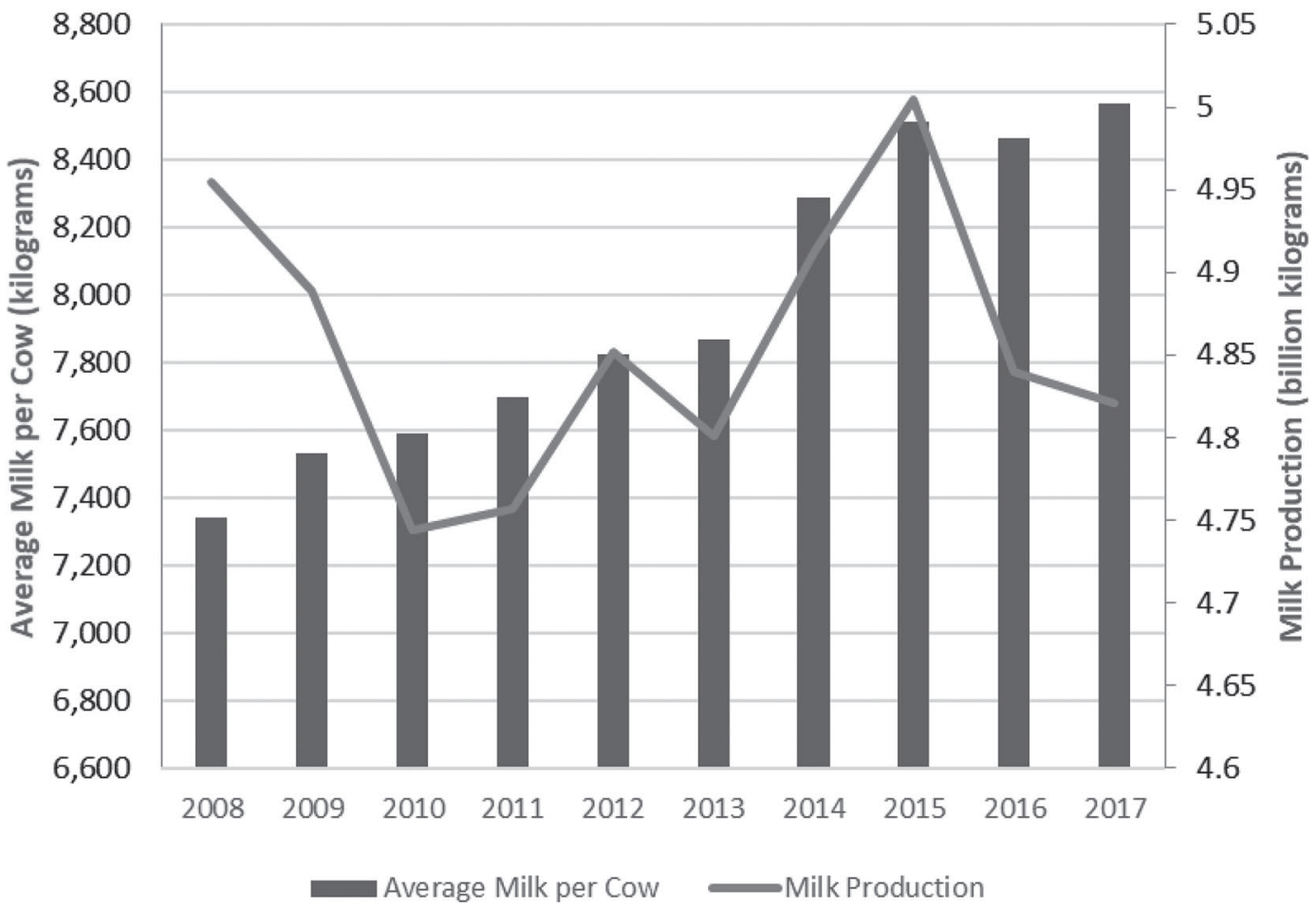

Figure 3. (a) Numbers of southeastern (SE) US dairy cows and herds, 2008 to 2017; (b) SE US dairy production, 2008 to 2017. Source: LMIC (2019a); USDA NASS (2019).

No known previous research has examined differences among operating versus closed dairies. However, previous studies have examined factors influencing dairy farm performance. Stup et al. (2006) examined human resource management practices and dairy farm performance. They found that dairies had higher return 
on equity when their employees received more hours of training, and dairies that used a feeding standard operating procedure had higher SCC than dairies that did not use a standard feeding operating procedure. Hadley et al. (2002) examined the managerial and financial implications of Michigan and Wisconsin dairy farm expansions. In their survey of dairy farm expansions, studied herds increased from 296 cows per farm to 569 cows per farm. The most commonly cited reason for expansion was increased profits; accordingly, net farm income and return to operator management and capital improved after expansion. Dairy farms also increased milk production and were able to decrease labor expenses during expansion. Mosheim and Lovell (2009) estimated scale economies in United States dairy farms, which were able to explain why average dairy farm size has been increasing. Haden and Johnson (1989) surveyed 81 Tennessee dairies, with herd sizes ranging from 28 to 240 cows per herd. They found that the primary contributor to financial success was increasing milk production per head, receiving higher milk prices, milking a large number of dairy cows, and controlling feed costs. Although much has changed in the dairy industry since 1989, it will be interesting to discover whether the findings of Haden and Johnson (1989) are consistent with results of the current study.

Research has also examined farm and operator attributes associated with BTSCC in dairies (Yalcin et al., 1999; Norman et al., 2000; Rodrigues and Ruegg, 2005; Valeeva et al., 2007; Wenz et al., 2007; Jansen et al., 2009; Schewe et al., 2015). Valeeva et al. (2007) and Jansen et al. (2009) found that whether producers received penalties or incentives for obtaining a certain BTSCC influenced mastitis management and BTSCC levels; Valeeva et al. (2007) found that penalties were more effective than incentives in motivating farmers to improve mastitis management.

Specific to the southeastern United States, DeLong et al. (2017) found several factors associated with dairy farm BTSCC levels. They constructed a scale of farmers' self-reported attitudes regarding their concern about mastitis on their farm and found that the more concerned farmers were about mastitis, the more likely they were to report higher BTSCC levels. DeLong et al. also found that increased BTSCC in the previous year and greater financial concerns regarding mastitis were also associated with higher BTSCC levels. Producers who obtained information about mastitis from veterinarians and extension personnel, producers who took action against mastitis at a BTSCC of less than 300,000 cells $/ \mathrm{mL}$, and increased perceived ability of producers to control mastitis were associated with lower BTSCC levels. We extend this research by examining farm characteristics and mastitis management practices associated with the operational status of southeastern US dairies.

\section{MATERIALS AND METHODS}

\section{Survey Design}

In 2013, a mail survey was sent to dairy farms in Georgia, Mississippi, Kentucky, North Carolina, South Carolina, Tennessee, and Virginia. All of the dairy farms in these states are Grade A, which means they qualify to sell Grade A dairy milk by meeting the requirements of the Grade A Pasteurized Milk Ordinance (FDA, 2019; USDA NASS, 2014). Grade A dairy milk is used for fluid milk consumption, whereas Grade B milk can be used only for butter, cheese, and other dairy products. The survey was sent also to dairy farms whose permits had been discontinued in the previous 5 years.

The survey included questions pertaining to farm business characteristics, operator attributes, dairy management practices, and perceptions and attitudes toward mastitis and mastitis management. The survey was mailed in October and November 2013, with 4 attempts at contact. Primary decision makers were asked to complete the survey. A total of 667 surveys were returned, from both operational and recently closed dairies. The response rate for the currently permitted dairies was 33\%; the response rate for those dairies with discontinued permits (the closed dairies) was $11 \%$. To benchmark survey respondents to the target dairy population, post-stratification weights were developed and used in statistical analyses (Lohr, 2010).

\section{Theoretical Model and Hypotheses}

Variables hypothesized to affect the operational status of a dairy include farm business characteristics, operator attributes, dairy management practices (e.g., mastitis management practices), and the sources of information used to treat or control for mastitis (Table $1)$. For producer $i$, period $t$, we hypothesize that operational status ( OpStatus $\left._{i t}\right)$ was explained as a function of the following factors:

$$
\text { OpStatus }_{i t}=f\left(F B C_{i}, O A_{i}, D M P_{i}, I S_{i}\right),
$$

where $F B C$ are variables associated with farm business characteristics, $O A$ are operator attributes, $D M P$ are dairy management practices, and $I S$ includes information sources producers received about treating and controlling mastitis.

Farm Business Characteristics. We hypothesized that larger and more productive farms would be 
operational due to efficiencies generated by scale economies (Haden and Johnson, 1989; Kumbhakar et al., 1991; Hadley et al., 2002; Mosheim and Lovell, 2009). Thus, we hypothesized that as the total number of cows on the farm and average milk production per cow increased, the farm was more likely to be operational (Table 1). Processors or co-ops may provide incentives if producers achieve low BTSCC or enforce penalties if producers exceed certain BTSCC. Similar to previous research (Valeeva et al., 2007; Jansen et al., 2009), we hypothesized that dairies whose co-op or processor imposed penalties (penalties) or offered incentives (incentives) would likely still be in operation. We hypothesized that dairies with more operations unrelated to their dairy (otherop) would be more likely to have exited the industry because the operator did not have enough time to manage the dairy. We were uncertain how the business structure of the operation (partner or solprop) would affect the operational status of a dairy. However, we hypothesized that business structure may correlate with the dairy's operational status, because DeLong et al. (2017) found that sole proprietorships had lower BTSCC than other business structures.

Operator Attributes. DeLong et al. (2017) found that BTSCC was higher on dairies with operators who spoke the same language as their employees. Thus, we expect that dairies will be more likely to be operational if its operators and employees do not speak the same language (language $=1$ ). Kumbhakar et al. (1991) found that education and the productivity of

Table 1. Variable definitions and hypothesized (hyp.) signs

\begin{tabular}{|c|c|c|}
\hline Variable & Definition & $\begin{array}{l}\text { Hyp. } \\
\text { signs }\end{array}$ \\
\hline \multicolumn{3}{|l|}{ Farm business characteristics } \\
\hline avgprod & Average milk production per cow per day (kg/d) & + \\
\hline totcows & Number of cows & + \\
\hline penalty & 1 if co-op or processor imposes a penalty for exceeding BTSCC ${ }^{1}$ & + \\
\hline incentive & 1 if co-op or processor imposes an incentive for particular BTSCC & + \\
\hline percoffinc & Total income from off farm $(\%)$ & + \\
\hline otherop & 1 if have farm operation not related to dairy & - \\
\hline solprop & 1 if the dairy business is a sole proprietorship & $+/-$ \\
\hline partner & 1 if the dairy business is a partnership & $+/-$ \\
\hline \multicolumn{3}{|l|}{ Operator attributes } \\
\hline language & 1 if the employees speak same language as owner or farm manager & + \\
\hline college & 1 if operator has college degree & + \\
\hline age & For operating dairy, age of operator. For closed dairy, age at dairy closure. & - \\
\hline newpractice & $\begin{array}{l}\text { Likert-scale question regarding how important it is to the farmer to adopt new } \\
\text { practices and technology }\end{array}$ & + \\
\hline fiancial_conseq & Likert-scale question regarding mastitis being a financial consequesnce ${ }^{1}$ & + \\
\hline \multicolumn{3}{|l|}{ Dairy management practices } \\
\hline Factor 1: Concern about mastitis & Factor 1 of the 18 Likert-scale questions regarding farmer perceptions of mastitis ${ }^{1}$ & + \\
\hline Factor 2: Mastitis is hard to control & Factor 2 of the 18 Likert-scale questions regarding farmer perceptions of mastitis ${ }^{1}$ & + \\
\hline everyday & 1 if in the parlor and doing the milking at almost every milking & - \\
\hline BTSCC_action & Lowest level of BTSCC that causes the farmer to take action & + \\
\hline mastplan & 1 if farmer has and implements mastitis management plan & + \\
\hline cull & 1 if farmer culls cows based on SCC information or other mastitis indicator & + \\
\hline act & 1 if farmer analyzes and acts on bacterial milk culture samples & + \\
\hline hygiene & 1 if using hygienic supplies for milking & + \\
\hline vaccine & 1 if using vaccines to control coliform mastitis & + \\
\hline antibiotic & 1 if routinely using antibiotic therapy to treat clinical mastitis cases & $+/-$ \\
\hline biosecurity & $\begin{array}{l}1 \text { if using biosecurity practices, such as pretesting or quarantine, for replacement } \\
\text { heifers and cows }\end{array}$ & + \\
\hline dhia & 1 if participates in DHIA testing & + \\
\hline adopt_dart & $\begin{array}{l}1 \text { if uses an electronic record-keeping system for tracking mastitis (PC-DART or } \\
\text { DairyComp- } 360^{3} \text { ) }\end{array}$ & + \\
\hline \multicolumn{3}{|c|}{ 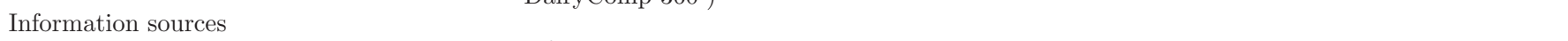 } \\
\hline vet & 1 from a veterinarian & + \\
\hline othprod & 1 from another dairy producer & + \\
\hline cooprep & 1 from milk cooperative representative & + \\
\hline extension & 1 from county agent or extension & + \\
\hline journal & 1 from farm journal & + \\
\hline drug & 1 from drug company & + \\
\hline
\end{tabular}

${ }^{1} \mathrm{BTSCC}=$ bulk tank SCC.

${ }^{2}$ Scale: 1 = strongly disagree, to $5=$ strongly agree.

${ }^{3}$ PC-DART, Dairy Records Management System, Raleigh, NC (http://www.drms.org/); DairyComp, Valley Agricultural Software, Tulare, CA (https://web.vas.com/). 
a dairy farm were positively associated. We therefore hypothesized that dairies that had operators who had a college degree (college $=1$ ) were more likely to be operational. We hypothesize operator age to have an influence on whether the dairy was operational. Age for closed dairies is the age of the operator at the time the dairy closed. Age for operating dairies is the operator's age at time the survey was taken. We expected that age (age) would reflect an operator's experience managing a dairy and overall knowledge of the dairy industry; however, we hypothesized that as the age of the operator increased, the dairy would be less likely to be in operation. This is due to the possibility of an older operator not adapting to newer technologies and marketing avenues that might make the operation more profitable. Research has found that older operators are less likely to participate in potential value-added marketing activities (Velandia et al., 2014; McLeod et al., 2018). Furthermore, older operators might not opt to make capital investments in their dairy if future generations do not wish to continue farming.

Dairy Management Practices. We hypothesized that dairies whose primary operator was in the parlor and doing the milking at almost every milking (everyday) were more likely to be operating, because DeLong et al. (2017) found that operators who milked every day had lower levels of BTSCC. If operators are in the parlor doing the milking at almost every milking, it is possible this is also indicative that the farm is more specialized and focused on dairy production, which may be reason for the farm to be more likely in operation. We hypothesized that producers who are more concerned about mastitis (higher scores on concern about mastitis factor), and those who have more control over their mastitis prevention practices (higher scores on mastitis is hard to control factor) would have a dairy still in operation. The BTSCC level that caused producer concern about mastitis (BTSCC_concern) was hypothesized to affect the operational status of the dairy. Specifically, we expect operators who reported a lower BTSCC concern level were more likely to be in operation. We also hypothesized that operators who acted on milk bacterial cultures (act) were more likely to be operational. If producers were actively trying to control mastitis, we expected them to be operational. Thus, dairies that used vaccines (vaccine), routinely used antibiotic therapy (antibiotic), or had a mastitis management plan (mastplan) were hypothesized to be more likely to be operational because they were taking steps to control mastitis.

Multiple programs can help detect and manage mastitis outbreaks. The Dairy Herd Improvement Association (DHIA) provides a network to help detect, manage and prevent mastitis. We hypothesized that producers who participated in DHIA testing (dhia) were more likely to be operational. Electronic record keeping (adopt_dart) can provide early and accurate detection of mastitis. Producers who used an electronic record-keeping system were hypothesized more likely to be operational.

Information Sources. We hypothesized that producers who received information from veterinarians (vet), other producers (othprod), milk cooperative representatives (cooprep), county extension agents (extension), farm journals (journal), and drug companies $(d r u g)$ were more likely to be operational.

\section{Data Analysis}

Probit regression was used to estimate which farm business characteristics, operator attributes, dairy management practices, and information sources were associated with the dairy's operational status. For operator $i$, OpStatus ( $1=$ open; $0=$ closed) was regressed on farm business characteristics, operator attributes, dairy management practices, and information sources:

$$
\text { OpStatus }_{i}=\beta_{0}+F B C_{i}+O A_{i}+D M P_{i}+I S_{i}+u_{i},
$$

with the following antecedents:

(a) Farm business characteristics:

$$
\begin{gathered}
\text { FBC }_{i}=\beta_{1} \cdot \text { avgprod }_{i}+\beta_{2} \cdot \text { totcows }_{i}+\beta_{3} \cdot \text { penalty }_{i} \\
+\beta_{4} \cdot \text {. }_{\text {incentive }}+\beta_{5} \cdot \text { percoffinc }_{i}+\beta_{6} \cdot \text { otherop }_{i} \\
+\beta_{7} \cdot \text { solprop }_{i}+\beta_{8} \cdot \text { partner }_{i},
\end{gathered}
$$

(b) Operator attributes:

$$
\begin{aligned}
& \text { OA }_{i}=\beta_{9} \cdot \text { language }_{i}+\beta_{10} \cdot \text { college }_{i}+\beta_{11} \cdot \text { age }_{i} \\
& +\beta_{12} \cdot \text { newpractice }_{i}+\beta_{13} \cdot \text { financial }_{\text {conse }_{i}}+\beta_{14} \cdot \text { expindex }_{i},
\end{aligned}
$$

(c) Dairy management practices:

$$
\begin{aligned}
& \text { DMP }_{i}=\beta_{15} \cdot \text { concern }_{i}+\beta_{16} \cdot \text { control }_{i}+\beta_{17} \cdot \text { everyday }_{i} \\
& +\beta_{18} \cdot \text { BTSCC }_{\text {action }_{i}}+\beta_{19} \cdot \text { mastplan }_{i}+\beta_{20} \cdot \text { cull }_{i}+\beta_{21} \cdot \text { act }_{i} \\
& +\beta_{22} \cdot \text {.ygiene }_{i}+\beta_{23} \cdot \text { vaccine }_{i}+\beta_{24} \cdot \text { antibiotic }_{i} \\
& +\beta_{25} \cdot \text { biosecurity }_{i}+\beta_{26} \cdot \text { dhia }_{i}+\beta_{27} \cdot \text { adopt_dart }_{i},
\end{aligned}
$$

(d) Information sources:

$$
\begin{gathered}
I S_{i}=\beta_{28} \cdot \text { info_vet }_{i}+\beta_{29} \cdot \text { info_cooprep }_{i} \\
+\beta_{30} \cdot \text { info_extension }_{i}+\beta_{31} \cdot \text { info_journal }_{i} \\
+\beta_{32} \cdot \text { info_drug }_{i},
\end{gathered}
$$


Table 2. Factor analysis of perceptions of mastitis and its management ${ }^{1}$

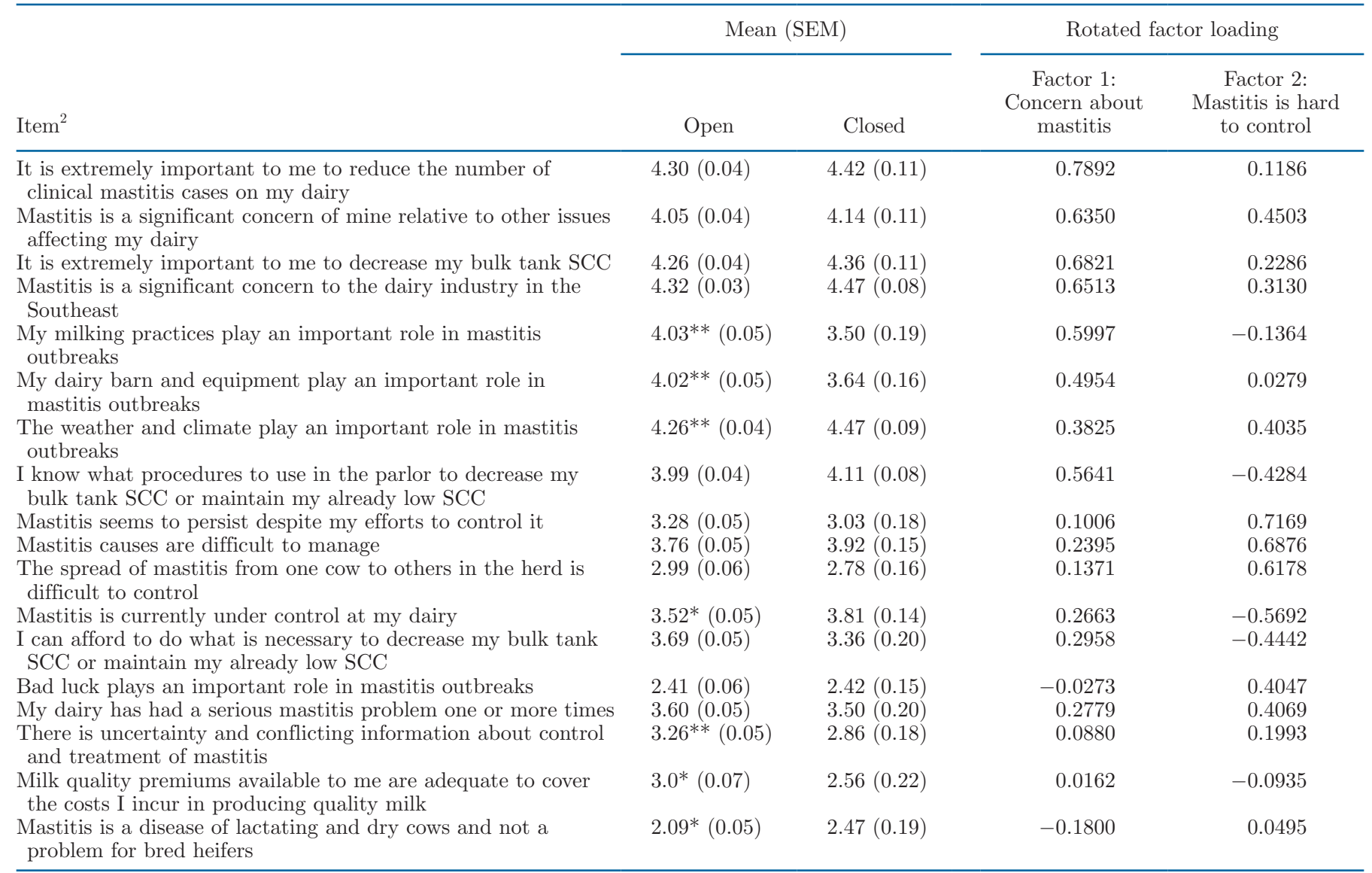

${ }^{1} \mathrm{n}=347$. Factor analysis was conducted using weights. Cronbach's $\alpha$ when considering statements with a rotated factor loading with an absolute value of 0.40 or greater for factor 1 and factor 2 was 0.73 and 0.64 , respectively.

${ }^{2}$ Questions were presented as follows: Please indicate the extent to which you disagree or agree with each of these statements, with $1=$ strongly disagree, $5=$ strongly agree.

${ }^{*} P<0.10,{ }^{* *} P<0.05$.

and where $u_{i}$ is an independent and identically distributed error term with a mean 0 and constant variance, and $\beta_{0}$ to $\beta_{32}$ are coefficients corresponding with the independent variables. Definitions of variables used in the model can be seen in Table 1 .

Two variables included in the model, "Factor 1: Concern about mastitis" and "Factor 2: Mastitis is hard to control," were created using factor analysis. A group of 18 Likert-scale questions related to farmer perceptions of mastitis and mastitis management were evaluated to generate summary factors associated with perceived farmer control of and concern about mastitis (Table 2). Summary factors were created using polychloric principal component analysis (Kolenikov and Ángeles, 2004). An example of an evaluated question was, "Please indicate the extent to which you disagree or agree with each of these statements: Mastitis is a significant concern of mine relative to other issues affecting my dairy." Response options ranged from $1=$ strongly disagree to
$5=$ strongly agree. Using polychoric principal component analysis, 2 factors were found given the questions. Cronbach's $\alpha$ for factor 1 (concern about mastitis) and factor 2 (mastitis is hard to control) were 0.7253 and 0.6417 , respectively. The higher the Cronbach's $\alpha$, the more the questions within the factors are related to each other (Goforth, 2015).

Differences in means of the descriptive statistics between operational versus closed dairies were evaluated for all the variables included in the probit regression. We conducted $t$-tests using the ttest command in Stata (StataCorp, 2017). The ex post power of the null hypotheses that the means of the variables were not different between operational and closed dairies was determined. We calculated the power of these mean comparisons, given the relatively low numbers of closed dairies available for analysis, and surmising that power calculations exceeding 0.80 indicate a well-powered test (Brown et al., 2019). The probit regression was 
estimated in Stata using the probit command, and the associated marginal effects were calculated using the margins command. Variance inflation factors were used to determine whether multicollinearity was a concern in the model, using the vif command.

\section{RESULTS}

\section{Survey Descriptive Statistics}

A total of 347 dairies completed all of the survey questions included in the probit regression. Of these dairies, 311 stated they were still operational, and 36 stated they were no longer in operation. The non-operational dairies closed from 2007 through 2014, with the major- ity of them $(38 \%)$ closing in 2012. To determine the power of the means comparisons tests, we conducted an ex post test of power, assuming a Type I error rate of $10 \%$, and under assumptions of normality (Brown et al., 2019). The population means of the closed-dairy group were considered the alternative distribution, under the null hypothesis that their means were not different from the mean estimates of all combined operations. The standard errors of the population mean were used as the variance for the power calculation $[$ Power $=1-$ $\operatorname{Pr}$ (Type II error)]; Pr = probability. Averaged over all statistical tests, the calculated power was $79 \%$, which approaches a reasonable threshold at which one can conclude that the sample of 36 closed dairies was large enough for good test power (Table 3 ).

Table 3. Means for the model by operational status

\begin{tabular}{|c|c|c|c|c|c|c|c|}
\hline \multirow[b]{2}{*}{ Variable $^{1}$} & \multicolumn{2}{|c|}{$\begin{array}{l}\text { All dairies } \\
\mathrm{n}=347\end{array}$} & \multicolumn{2}{|c|}{$\begin{array}{l}\text { Open dairies } \\
\mathrm{n}=311\end{array}$} & \multicolumn{2}{|c|}{$\begin{array}{l}\text { Closed dairies } \\
\quad \mathrm{n}=36\end{array}$} & \multirow[b]{2}{*}{ Power $^{2}$} \\
\hline & Mean & SEM & Mean & SEM & Mean & SEM & \\
\hline \multicolumn{8}{|l|}{ Farm business characteristics } \\
\hline $\operatorname{avgprod}(\mathrm{kg} / \mathrm{d})$ & 26.31 & 0.37 & $26.82^{* * *}$ & 0.37 & 20.90 & 1.20 & 1.00 \\
\hline totcows (no.) & 205.54 & 29.07 & $218.69 * * *$ & 32.33 & 92.08 & 10.80 & 0.99 \\
\hline penalty & 0.72 & 0.02 & $0.74^{* * *}$ & 0.02 & 0.50 & 0.08 & 1.00 \\
\hline incentive & 0.85 & 0.02 & $0.88^{* * *}$ & 0.02 & 0.64 & 0.08 & 1.00 \\
\hline percoffinc & 0.02 & 0.07 & 0.02 & 0.07 & 0.02 & 0.24 & 0.10 \\
\hline otherop & 0.36 & 0.03 & $0.34^{* *}$ & 0.03 & 0.53 & 0.08 & 1.00 \\
\hline solprop & 0.61 & 0.03 & $0.58 * * *$ & 0.03 & 0.81 & 0.07 & 1.00 \\
\hline partner & 0.22 & 0.02 & 0.23 & 0.02 & 0.14 & 0.06 & 0.99 \\
\hline \multicolumn{8}{|l|}{ Operator attributes } \\
\hline language & 0.86 & 0.02 & 0.85 & 0.02 & 0.92 & 0.05 & 0.92 \\
\hline college & 0.31 & 0.02 & 0.31 & 0.03 & 0.31 & 0.08 & 0.10 \\
\hline $\operatorname{age}(\mathrm{yr})$ & 50.62 & 0.74 & $49.86^{* * *}$ & 0.78 & 57.58 & 1.88 & 1.00 \\
\hline newpractice & 0.35 & 0.03 & 0.35 & 0.03 & 0.36 & 0.08 & 0.13 \\
\hline fiancial_conseq (Likert-scale score) & 4.45 & 0.04 & 4.44 & 0.04 & 4.56 & 0.09 & 0.87 \\
\hline \multicolumn{8}{|l|}{ Dairy management practices } \\
\hline $\begin{array}{l}\text { Factor 1: Concern about mastitis } \\
\text { (Likert-scale score) }\end{array}$ & 6.05 & 0.03 & 6.05 & 0.04 & 6.01 & 0.11 & 0.38 \\
\hline $\begin{array}{l}\text { Factor 2: Mastitis is hard to control } \\
\text { (Likert-scale score) }\end{array}$ & 1.63 & 0.04 & 1.16 & 0.04 & 1.64 & 0.13 & 0.11 \\
\hline everyday & 0.38 & 0.03 & $0.35^{* * *}$ & 0.03 & 0.67 & 0.08 & 1.00 \\
\hline BTSCC_concern (cells/mL) & 345,000 & 0.07 & $337,000^{* *}$ & 0.07 & 401,000 & 0.27 & 1.00 \\
\hline mastplan & 0.68 & 0.03 & $0.67^{*}$ & 0.03 & 0.81 & 0.07 & 0.99 \\
\hline cull & 0.85 & 0.02 & 0.86 & 0.02 & 0.75 & 0.07 & 1.00 \\
\hline act & 0.38 & 0.03 & $0.35^{* *}$ & 0.03 & 0.58 & 0.08 & 1.00 \\
\hline hygiene & 0.85 & 0.02 & 0.88 & 0.02 & 0.86 & 0.06 & 0.16 \\
\hline vaccine & 0.46 & 0.03 & $0.49 * * *$ & 0.03 & 0.19 & 0.07 & 1.00 \\
\hline antibiotic & 0.82 & 0.02 & $0.81^{*}$ & 0.02 & 0.92 & 0.05 & 1.00 \\
\hline biosecurity & 0.10 & 0.02 & 0.09 & 0.02 & 0.14 & 0.06 & 0.66 \\
\hline dhia & 0.59 & 0.03 & $0.61^{* *}$ & 0.03 & 0.42 & 0.08 & 1.00 \\
\hline adopt_dart & 0.24 & 0.02 & $0.25^{* *}$ & 0.02 & 0.11 & 0.05 & 1.00 \\
\hline \multicolumn{8}{|l|}{ Information sources } \\
\hline vet & 0.92 & 0.01 & 0.92 & 0.02 & 0.89 & 0.05 & 0.87 \\
\hline othprod & 0.78 & 0.02 & 0.77 & 0.02 & 0.83 & 0.06 & 0.90 \\
\hline cooprep & 0.19 & 0.03 & 0.52 & 0.03 & 0.50 & 0.08 & 1.00 \\
\hline extension & 0.33 & 0.03 & 0.33 & 0.03 & 0.31 & 0.08 & 0.22 \\
\hline journal & 0.59 & 0.03 & 0.58 & 0.03 & 0.67 & 0.08 & 0.81 \\
\hline$d r u g$ & 0.31 & 0.02 & $0.31^{*}$ & 0.03 & 0.19 & 0.07 & 1.00 \\
\hline
\end{tabular}

${ }^{1}$ Variables are defined in Table 1.

${ }^{2}$ Averaged over all ex post power tests, power $=0.79$.

${ }^{*} P<0.10,{ }^{* *} P<0.05,{ }^{* * *} P<0.01$. 
Farm Business Characteristics. On average, operational dairies managed 219 milk cows, and their cows had an average production of $26.82 \mathrm{~kg} / \mathrm{d}$, whereas closed dairies had 92 milk cows $(P<0.01)$ and an average production of $20.90 \mathrm{~kg} / \mathrm{d}(P<0.01$; Table $3)$. Operational dairies affiliated with processors or cooperatives that imposed penalties represented $74 \%$, whereas $50 \%$ of closed operations were affiliated with penalty-imposing processors $(P<0.01)$. Operational dairies affiliated with processors or cooperatives who offered incentives for obtaining a certain BTSCC target on average represented $88 \%$ of the sample; $64 \%$ of respondents who had exited the industry were affiliated with processors or cooperatives who offered incentives for a target BTSCC level $(P<0.01)$. The percent of operational dairies who had other operations unrelated to the dairy (otherop) was $34 \%$, whereas $53 \%$ of closed dairies had other operations $(P<0.05)$; $58 \%$ of operational dairies indicated they were sole proprietorships, compared with $81 \%$ of closed dairies $(P<0.01)$.

Operator Attributes. On average, $85 \%$ of the operational dairies had operators and employees who spoke the same language, and $92 \%$ of closed dairies had operators and employees who spoke the same language. Thirty-one percent of both operational and closed dairy operators had a college education. On average, operational dairies had operators who were 50 years of age when they completed the survey, compared with closed dairies, whose operators were 58 years of age, on average, at the time the dairy ceased operation $(P<0.01)$.

Dairy Management Practices. The percent of operators from an operational dairy who participated in the milking every day was $35 \%$, whereas $67 \%$ of operators of closed dairies were involved $(P<0.01)$. The average score for concern about mastitis was not significantly different between closed and operational dairies, at 6.05 and 6.01 , respectively. The average score for mastitis is hard to control was 1.16 and 1.64 for operational and closed dairies, respectively. On average, operational dairies reported lower thresholds at which BTSCC became a concern $(337,000$ cells $/ \mathrm{mL})$ than closed dairies did $(401,000$ cells $/ \mathrm{mL} ; P<0.05)$. On average, $35 \%$ of operational dairies were acting on bacterial cultures, whereas $58 \%$ of the closed dairies were acting on cultures $(P<0.05)$. Forty-nine percent of the operational dairies used vaccines, on average, whereas $19 \%$ of the closed operations used vaccines $(P$ $<0.01$ ). Sixty-one percent of operational dairies and $42 \%$ of closed dairies were participants in the DHIA network $(P<0.05)$. On average, $25 \%$ of operational dairies used an electric record-keeping system (e.g., PC-DART or DairyComp-305) for tracking mastitis, and $11 \%$ of closed dairies used such technology $(P<$ $0.05)$.
Information Sources. We found little difference between operational and closed dairies, on average, in use of the various sources of information about mastitis (Table 3).

\section{Probit Regression Results}

Table 4 displays the probit regression results and associated marginal effects. The mean variance inflation factor was 1.36 , with 2.22 being the highest value. Thus, multicollinearity was not a concern. The estimated probit regression had a pseudo $\mathrm{R}^{2}$ of 0.48 , and the Wald $\chi^{2}$ statistic with 32 degrees of freedom was significant $(P<0.001)$.

Farm Business Characteristics. Results indicate that dairy farms with more cows (totcows) and higher average daily milk production per cow (avgprod) were more likely to be operational. As a farm's average milk production per cow per day increased by $10 \mathrm{~kg} / \mathrm{d}$, the farm was $1.5 \%$ more likely to be operational $(P=$ $0.003)$. For an additional 100 cows a dairy managed, it was $4 \%$ more likely to be operational $(P=0.012)$. The likelihood of a dairy to still be in operation increased by $7 \%(P=0.030)$ if its cooperative or processor imposed penalties (penalty) and by $8 \%(P=0.022)$ if the dairy was incentivized to perform at a certain level (incentive).

Operator Attributes. The likelihood a dairy was still operational increased by $7 \%(P=0.045)$ if the operator and employees spoke the same language (language). Older dairy operators were less likely to be operational. For a 1-yr increase in the operator's age (age), the dairy was $4 \%$ less likely to be operational ( $P$ $=0.001)$.

Farm Management Practices. One of the factor analysis variables included in the model was statistically significant. As producers found mastitis to be hard to control (mastitis is hard to control), they were $5 \%$ more likely to be operational $(P=0.018)$. Operators who were involved in the milking every day (everyday) were $8 \%$ less likely to have an operational dairy $(P=0.003)$. Consistent with expectations, as the BTSCC level that caused the operator concern increased (BTSCC_concern $)$, the dairy was $3 \%(P=0.001)$ less likely to be in operation.

If the operation had a mastitis management plan in place (mastplan), they were $8 \%(P=0.006)$ less likely to be in operation. Acting on bacterial cultures in milk samples (act) decreased the likelihood of the dairy being in operation by $8 \%(P=0.003)$. Using antibiotic therapy to treat clinical mastitis (antibiotic) decreased the likelihood of the dairy still being in operation by 9\% $(P=0.013)$. 
Information Sources. Dairy producers who received information about mastitis from farm journals (journal) were $5 \%$ less likely to have an operational dairy $(P=0.076)$.

\section{DISCUSSION}

Consistent with previous research (Haden and Johnson, 1989; Hadley et al., 2002; Mosheim and Lovell, 2009), this paper confirms the trend of dairy consolidation in the United States into larger and more productive farms. The dairy industry has gone through a number of changes since 1989 , but our results, that farms with higher average milk production per cow and greater numbers of cows were more likely to be operational, are consistent with those of Haden and Johnson (1989). They found that increasing milk production per head and milking a larger number of dairy cows in Tennessee was associated with greater financial success. Despite our findings that farms with greater numbers of cows and more productive cows were more likely to be operational, it should be noted that this is not intended to mean that farmers who increase their herd size and productivity per cow will be more likely to be operational. Increasing per-cow milk production or herd size may not be financially feasible for all dairy producers, and both strategies bring added risk. Therefore, although our results show that an additional 100

Table 4. Probit model results and marginal effects: determinants of operational status

\begin{tabular}{|c|c|c|c|c|}
\hline Variable $^{1}$ & Coefficient & $\mathrm{SE}^{2}$ & $\begin{array}{l}\text { Marginal } \\
\text { effect }\end{array}$ & $\mathrm{SE}$ \\
\hline \multicolumn{5}{|l|}{ Farm business characteristics } \\
\hline avgprod & $0.0151^{* * *}$ & 0.0055 & $0.0015^{* * *}$ & 0.0005 \\
\hline totcows & $0.0041^{* * *}$ & 0.0016 & $0.0004^{* *}$ & 0.0002 \\
\hline penalty ${ }^{3}$ & $0.6918^{* *}$ & 0.3285 & $0.0662^{* *}$ & 0.0305 \\
\hline incentive $^{3}$ & $0.8398^{* *}$ & 0.3704 & $0.0804^{* *}$ & 0.0350 \\
\hline percoffinc ${ }^{3}$ & -0.0239 & 0.1153 & -0.0023 & 0.0111 \\
\hline otherop 3 & -0.3873 & 0.2647 & -0.0371 & 0.0257 \\
\hline solprop $^{4}$ & 0.0636 & 0.4387 & 0.0061 & 0.0419 \\
\hline partner ${ }^{4}$ & 0.5064 & 0.4603 & 0.0485 & 0.0429 \\
\hline \multicolumn{5}{|l|}{ Operator attributes } \\
\hline language & $0.7389^{*}$ & 0.3879 & $0.0707^{* *}$ & 0.0353 \\
\hline college $e^{3}$ & 0.0353 & 0.3303 & 0.0034 & 0.0316 \\
\hline age & $-0.0374^{* * *}$ & 0.0111 & $-0.0036^{* * *}$ & 0.0011 \\
\hline newpractice & 0.0493 & 0.2867 & 0.0047 & 0.0275 \\
\hline fiancial_conseq & -0.3470 & 0.2448 & -0.0332 & 0.0236 \\
\hline \multicolumn{5}{|l|}{ Dairy management practices } \\
\hline Factor 1: Concern about mastitis & 0.1050 & 0.2141 & 0.0101 & 0.0206 \\
\hline Factor 2: Mastitis is hard to control & $0.4737^{* *}$ & 0.1950 & $0.0453^{* *}$ & 0.0191 \\
\hline everyday ${ }^{3}$ & $-0.8817^{* * *}$ & 0.3004 & $-0.0844^{* * *}$ & 0.0284 \\
\hline BTSCC_concern & $-0.3468 * * *$ & 0.1034 & $-0.0332 * * *$ & 0.0096 \\
\hline mastplan ${ }^{3}$ & $-0.8114^{* * *}$ & 0.3010 & $-0.0777 * * *$ & 0.0283 \\
\hline cull $^{3^{2}}$ & 0.3968 & 0.2926 & 0.0380 & 0.0279 \\
\hline$a c t^{3}$ & $-0.8233^{* * *}$ & 0.2846 & $-0.0788^{* * *}$ & 0.0263 \\
\hline hygiene $^{3}$ & -0.3516 & 0.4086 & -0.0337 & 0.0391 \\
\hline vaccine $e^{3}$ & $0.4709^{*}$ & 0.2857 & $0.0451^{*}$ & 0.0271 \\
\hline antibiotic $^{3}$ & $-0.9671^{* * *}$ & 0.3677 & $-0.0926^{* *}$ & 0.0373 \\
\hline biosecurity $^{3}$ & 0.2998 & 0.3831 & 0.0287 & 0.0369 \\
\hline$d h i a^{3}$ & -0.4399 & 0.2921 & -0.0421 & 0.0274 \\
\hline adopt_dart ${ }^{3}$ & -0.1907 & 0.3870 & -0.0183 & 0.0375 \\
\hline \multicolumn{5}{|l|}{ Information sources } \\
\hline vet & 0.0331 & 0.4077 & 0.0032 & 0.0391 \\
\hline othprod & -0.3812 & 0.3119 & -0.0365 & 0.0299 \\
\hline cooprep & 0.2772 & 0.2612 & 0.0265 & 0.0248 \\
\hline extension & -0.2402 & 0.2961 & -0.0230 & 0.0287 \\
\hline journal & $-0.5087^{*}$ & 0.2893 & $-0.0487^{* *}$ & 0.0275 \\
\hline drug & 0.0192 & 0.3229 & 0.0018 & 0.0309 \\
\hline Constant & $3.6630^{*}$ & 1.9563 & & \\
\hline Pseudo $\mathrm{R}^{2}$ & 0.4843 & & & \\
\hline Wald $\chi^{2}(32 \mathrm{df})$ & $111.05^{* * *}$ & & & \\
\hline
\end{tabular}

${ }^{1}$ Variables are defined in Table 1.

${ }^{2}$ Robust regression SE. $\mathrm{n}=347$.

${ }^{3}$ Coded as 1 if selected and -1 otherwise.

${ }^{4}$ Compared with a corporation or other entity definition.

$* P<0.10,{ }^{* *} P<0.05, * * * P<0.01$. 
cows increases the probability that a dairy farm would be operational by $4 \%$, this may be too costly to achieve to be economically feasible for certain dairies and may not result in a greater likelihood of being operational.

We also found that producers who received a penalty or incentive for reaching a certain BTSCC level were $7 \%$ and $8 \%$ more likely to have an operational dairy, respectively. This shows that regardless of whether dairies were incentivized with rewards or penalties, they were nearly equally more likely to be operational. This is somewhat contrary to Valeeva et al. (2007), who found that penalties were more effective in motivating farmers to improve mastitis management.

Our study found that $86 \%$ of surveyed producers spoke the same language as their employees. This is somewhat counter to the findings of Stup et al. (2006), that $29 \%$ of the dairies they surveyed in Pennsylvania had employees who spoke Spanish as their first language. In our study, dairies with operators and employees who spoke the same language were slightly more likely to be operational. However, DeLong et al. (2017) found that BTSCC was higher on dairies with operators who spoke the same language as their employees. Therefore, results are mixed as to how sharing a first language influences overall farm performance.

As dairy operators aged, we found that the dairy was less likely to be operational. It is possible that as producers age, they are less likely to adopt new technologies and marketing avenues or to expand their dairy, which could contribute to the dairy's viability and profitability. This finding may also suggest that dairy operators without farm transition plans or a family member or non-family member identified to succeed them in dairy operations are more likely to retire from the dairy later in life than those who have someone to succeed them as the dairy operator. Additionally, this could indicate that the dairy operator had no descendants who currently worked on the dairy or who wanted to eventually operate the dairy.

A dairy was more likely to be operational if the operators were not in the parlor doing the milking at almost every milking. This result could be indicative of larger dairies, which are more likely to be operational, not having their primary operator involved in physically milking every day, considering that they would potentially employ hired labor to do the milking. This result contradicts the results reported by DeLong et al. (2017), who found that operators who were doing the milking at almost every milking had lower BTSCC levels.

DeLong et al. (2017) found that producers who took action to control mastitis at a lower BTSCC level were more likely to have a lower BTSCC. Similarly, we found that producers who took action to control mastitis at lower levels of BTSCC (BTSCC_action) were more likely to be operational, which is consistent with expectations. As producers found mastitis to be harder to control, they were more likely to be operational. This result is opposite from our hypothesis. One possible explanation is that operational dairies recognize and noted the challenges associated with managing mastitis more so than dairies that have closed. However, further research is needed to fully understand this result. Producers who implemented a mastitis management plan, acted on bacterial cultures in milk samples, used hygienic supplies for milking, and routinely used antibiotic therapy to treat mastitis were less likely to have an operational dairy. Although these results show opposite signs from our hypotheses, it is possible that having a mastitis plan, acting on bacterial milk samples, and using antibiotic therapy to treat clinical mastitis are all indicative of an underlying mastitis problem at the dairy. If this is the case, it is consistent with expectations that dairies with mastitis problems would no longer be operational.

Unexpectedly, most sources of information were not associated with operational status, and results suggested that producers who rely on information from farm journals were less likely to be operational. This could be indicative of non-operational dairies relying on farm journals for information and operational dairies being more likely to use other information sources, such as extensions and veterinarians.

An extension of this research would be to include farm financial information in the questionnaire to determine how financial ratios (e.g., debt-to-asset ratio) contribute to the likelihood of a dairy remaining operational, and to conduct this survey at a national level. Furthermore, the inclusion of questions in the survey regarding whether the dairies participated in any value-added marketing of their dairy products could provide valuable information. It would be interesting to know whether the dairy was organic or used its milk to produce ice cream or cheese that were directly sold to grocery stores or consumers. Also, information linking where the milk was ultimately sold (e.g., domestically, which US region) would be of interest to include in future studies.

\section{CONCLUSIONS}

Throughout the United States, the dairy industry has been consolidating into larger and more efficient dairies. In the past decade, the number of dairy farms in the southeastern United States has declined by $39 \%$. We analyzed the differences in farm and operator characteristics of dairies that are in operation versus those that have exited the industry in the southeastern 
United States. Similar to previous studies and dairy industry demographics, we found that dairy farms with a greater number of cows and higher average daily milk production per cow were more likely to be operational. Results provide useful information regarding farm business practices, operator attributes, dairy management characteristics (e.g., mastitis management), and information sources used among operational and nonoperational dairies in the southeastern United States. Results show not only that operations that are capable of leveraging scale effects are more likely to be operational, but also that other significant mastitis management factors are associated with the operational status of southeastern US dairies.

\section{ACKNOWLEDGMENTS}

This material is based upon work supported by the USDA National Institute of Food and Agriculture (Washington, DC), under award number 2013-6800420424. Any opinions, findings, conclusions, or recommendations expressed in this publication are those of the authors and do not necessarily reflect the views of the USDA. The authors have not stated any conflicts of interest.

\section{REFERENCES}

Barkema, H. W., N. A. G. von Keyserlingk, J. P. Kastelic, T. J. G. M. Lam, C. Luby, J.-P. Roy, S. J. LeBlanc, G. P. Keefe, and D. F. Kelton. 2015. Invited review: Changes in the dairy industry affecting dairy cattle health and welfare. J. Dairy Sci. 98:7426-7445. https://doi.org/10.3168/jds.2015-9377.

Brown, J. P., D. M. Lambert, and T. R. Wojan. 2019. The effect of the Conservation Reserve Program on rural economies: Deriving a statistical verdict from a null finding. Am. J. Agric. Econ. 101:528-540. https://doi.org/10.1093/ajae/aay046.

DeLong, K. L., D. M. Lambert, S. Schexnayder, P. Krawczel, M. Fly, L. Garkovich, and S. Oliver. 2017. Farm business and operator variables associated with bulk tank somatic cell count from dairy herds in the Southeastern United States. J. Dairy Sci. 100:9298 9310. https://doi.org/10.3168/jds.2017-12767.

FDA (Food and Drug Administration). 2019. Grade A Pasteurized Milk Ordinance. Accessed December 12, 2019. https://www.fda .gov/media/114169/download.

Goforth, C. 2015. Using and interpreting Cronbach's alpha. University of Virginia Library Research Data Services and Sciences. Accessed Oct. 16, 2018. https://data.library.virginia.edu/using-and -interpreting-cronbachs-alpha/.

Haden, K. L., and L. A. Johnson. 1989. Factors which contribute to the financial performance of selected Tennessee dairies. J. Agric. Appl. Econ. 21:105-112. https://doi.org/10.1017/S0081305200000960.

Hadley, G. L., S. B. Harsh, and C. A. Wolf. 2002. Managerial and financial implications of major dairy farm expansions in Michigan and Wisconsin. J. Dairy Sci. 85:2053-2064. https://doi.org/10 .3168/jds.S0022-0302(02)74283-5.

Herndon, C. W. 2011. How the southeast is different. Hoard's Dairyman. Accessed Jul. 16, 2018. https://hoards.com/article-2392 -hoard's-dairyman-article-how-the-southeast-is-different.html.

Jansen, J., B. H. P. Van den Borne, R. J. Renes, G. van Schaik, T. J. G. M. Lam, and C. Leeuwis. 2009. Explaining mastitis incidence in Dutch dairy farming: The influence of farmers' attitudes and behaviour. Prev. Vet. Med. 92:210-223. https://doi.org/10.1016/j .prevetmed.2009.08.015.

Kolenikov, S., and G. Ángeles. 2004. The use of discrete data in PCA: Theory, simulations, and applications to socioeconomic indices. Carolina Population Center, University of North Carolina, Chapel Hill. Accessed Oct. 16, 2018. https://www.measureevaluation.org/ resources/publications/wp-04-85.

Kumbhakar, S. C., S. Ghosh, and J. T. McGuckin. 1991. A generalized production frontier approach for estimating determinants of inefficiency in U.S. dairy farms. J. Bus. Econ. Stat. 9:279-286.

LMIC (Livestock Marketing Information Center). 2019a. Milk Production, Inventory-Annual. Accessed Feb. 25, 2019. https://www.lmic .info/spreadsheet/prices-and-production.

LMIC (Livestock Marketing Information Center). 2019b. Product/ Milk Prices. Accessed Feb. 25, 2019. https://www.lmic.info/quick _market_reports/diary.

Lohr, S. L. 2010. Sampling: Design and Analysis. 2nd ed. Brooks/Cole Publishing Co., Pacific Grove, CA

McLeod, E., K. Jensen, A. P. Griffith, and K. L. DeLong. 2018. Tennessee beef producers' willingness to participate in a state branded beef program. J. Agric. Appl. Econ. 50:579-601. https://doi.org/ 10.1017/aae.2018.16.

Mosheim, R., and C. A. K. Lovell. 2009. Scale economies and inefficiency of U.S. dairy farms. Am. J. Agric. Econ. 91:777-794. https: //doi.org/10.1111/j.1467-8276.2009.01269.x.

National Mastitis Council. 1999. Laboratory Handbook on Bovine Mastitis. 2nd ed. National Mastitis Council, New Prague, MN.

Norman, H. D., R. H. Miller, J. R. Wright, and G. R. Wiggans. 2000. Herd and state means for somatic cell count from dairy herd improvement. J. Dairy Sci. 83:2782-2788. https://doi.org/10.3168/ jds.S0022-0302(00)75175-7.

Oliver, S. P., B. E. Gillespie, S. J. Headrick, H. Moorehead, P. Lunn, H. H. Dowlen, D. L. Johnson, K. C. Lamar, S. T. Chester, and W. M. Moseley. 2004. Efficacy of extended ceftiofur intramammary therapy for treatment of subclinical mastitis in lactating dairy cows. J. Dairy Sci. 87:2393-2400. https://doi.org/10.3168/ jds.S0022-0302(04)73361-5.

Pighetti, G. M., and A. A. Elliott. 2011. Gene polymorphisms: The keys for marker assisted selection and unraveling core regulatory pathways for mastitis resistance. J. Mammary Gland Biol. Neoplasia 16:421-432. https://doi.org/10.1007/s10911-011-9238-9.

Pighetti, G. M., S. P. Oliver, R. A. Almeida, P. D. Krawczel, J. M. Fly, S. M. Schexnayder, C. S. Petersson-Wolfe, J. M. Bewley, L. E. Garkovich, D. M. Amaral-Phillips, L. M. Arnold, S. C. Nickerson, S. Hill Ward, and A. DeVries. 2014. Southeast Quality Milk Initiative: Milk quality in the Southeast USA. Pages 209-210 in Proc. National Mastitis Council Annual Meeting.

Rodrigues, A. C. O., and P. L. Ruegg. 2005. Actions and outcomes of Wisconsin dairy farms completing milk quality teams. J. Dairy Sci. 88:2672-2680. https://doi.org/10.3168/jds.S0022-0302(05)72944 $-1$.

Schewe, R. L., J. Kayitsinga, G. A. Contreras, C. Odom, W. A. Coats, P. Durst, E. P. Hovingh II, R. O. Martinez, R. Mobley, S. Moore, and R. J. Erskine. 2015. Herd management and social variables associated with bulk tank somatic cell count in dairy herds in the eastern United States. J. Dairy Sci. 98:7650-7665. https://doi.org/ $10.3168 /$ jds.2014-8840.

StataCorp. 2017. Stata Statistical Software. 15th ed. StataCorp, College Station, TX.

Stup, R. E., J. Hyde, and L. A. Holden. 2006. Relationships between selected human resource management practices and dairy farm performance. J. Dairy Sci. 89:1116-1120. https://doi.org/10.3168/ jds.S0022-0302(06)72180-4.

United States Department of Labor. 2019. Bureau of Labor Statistics: CPI inflation calculator. Accessed Dec. 10, 2019. https://data.bls .gov/cgi-bin/cpicalc.pl.

USDA-APHIS (Animal and Plant Health Inspection Service). 2013. Determining U.S. milk quality using bulk-tank somatic cell counts, 2013. Accessed Feb. 26, 2019. https://www.aphis.usda.gov/animal _health/nahms/dairy/downloads/dairy_monitoring/BTSCC _2013infosheet.pdf. 
USDA-APHIS (Animal and Plant Health Inspection Service). 2018. Determining U.S. milk quality using bulk-tank somatic cell counts, 2017. Accessed Feb. 26, 2019. https://www.aphis.usda.gov/animal _health/nahms/dairy/downloads/dairy_monitoring/BTSCC 2017infosheet.pdf.

USDA-ERS (Economic Research Service). 2019. FAQ. U.S. Department of Agriculture, ERS. Accessed Jan. 15, 2019. https://www .ers.usda.gov/faqs/\#Q2.

USDA-NASS (National Agricultural Statistics Service). 2014. Milk production, disposition, and income: 2014 summary. Accessed Dec. 18, 2019. https://downloads.usda.library.cornell.edu/usda -esmis/files/4b29b5974/q237hv80t/m900nx003/MilkProdDi-04-30 -2015.pdf.

USDA-NASS (National Agricultural Statistics Service). 2018. Milk production, disposition, and income: 2017 summary. U.S. Department of Agriculture. Accessed Jan. 10, 2019. https://downloads .usda.library.cornell.edu/usda-esmis/files/4b29b5974/4j03d209m/ qr46r324g/MilkProdDi-04-26-2018.pdf.

USDA-NASS (National Agricultural Statistics Service). 2019. Milk production quarterly publications. Accessed Jan. 15, 2019. https: //usda.library.cornell.edu/concern/publications/h989r321c?locale $=\mathrm{en}$.

Valeeva, N. I., T. J. G. M. Lam, and H. Hogeveen. 2007. Motivation of dairy farmers to improve mastitis management. J. Dairy Sci. 90:4466-4477. https://doi.org/10.3168/jds.2007-0095.
Velandia, M., C. D. Clark, D. M. Lambert, J. A. Davis, K. Jensen, A. Wszelaki, and M. D. Wilcox Jr.. 2014. Factors affecting producer participation in state-sponsored marketing programs: The case of fruit and vegetable growers in Tennessee. Agric. Resour. Econ. Rev. 43:249-265. https://doi.org/10.1017/S1068280500004305.

Wenz, J. R., S. M. Jensen, J. E. Lombard, B. A. Wagner, and R. P. Dinsmore. 2007. Herd management practices and their association with bulk tank somatic cell count on United States dairy operations. J. Dairy Sci. 90:3652-3659. https://doi.org/10.3168/ jds.2006-592.

Yalcin, C., A. W. Stott, D. N. Logue, and J. Gunn. 1999. The economic impact of mastitis-control procedures used in Scottish dairy herds with high bulk-tank somatic-cell counts. Prev. Vet. Med. 41:135-149. https://doi.org/10.1016/S0167-5877(99)00052-5.

\section{ORCIDS}

Karen L. DeLong (ํ) https://orcid.org/0000-0002-6352-7171

Susan Schexnayder $\odot$ https://orcid.org/0000-0002-8803-7072

Peter Krawczel ৫ https://orcid.org/0000-0002-9867-2280 